\title{
MUUTTUVAT LAULUT \\ MELODIATOISINTOJEN MUUNTUMISEN TODENNÄKÖISYYDEN ENNUSTAMINEN MUSIIKILLISILLA MUUTTUJILLA
}

Kuulonvaraiseen oppimiseen perustuvissa musiikkiperinteissä sävelmillä ei ole kiinteää muotoa, vaan ne ilmenevät erilaisina toisistaan enemmän tai vähemmän poikkeavina toisintoina. Englantilainen kansanperinteen elvyttäjä Cecil Sharp (1907: 10) näki kansanlaulujen olevan jatkuvan luonnonvalinnan kaltaisen prosessin alaisena, jossa yhteisö hyväksyy toisinnot, jotka vetoavat parhaiten tavallisiin laulajiin ja hylkää toisinnot, jotka eivät vastaa yhteisön makua. Epäilemättä eri musiikkikulttuureissa on erilaisia toisistaan poikkeavia käsityksiä hyvästä toisinnosta, mutta onko olemassa yleisiä lainalaisuuksia, jotka selittävät melodista muuntelua?

Kysymys, milloin melodia muuttuu todennäköisimmin, on ollut yksi keskeisistä tutkimuskysymyksistä systemaattisen musiikkitieteen historiassa. Suomalaisittain mielenkiintoista on, että Ilmari Krohnilla on ollut keskeinen asema tutkimusalueen muotoutumisessa (Bereczky 2001: 14-18). Suomalaista tutkimusperinnettä on jatkanut Jukka Louhivuori (1988), joka tutki kysymystä tietokoneavusteisesti käyttäen tilastollisia menetelmiä. Aihepiirin tutkimus on kuitenkin edelleen ajankohtaista useasta syystä. Musiikin hahmottamista käsittelevien tutkimusten perusteella voidaan olettaa, että sävelmän muuntumisen todennäköisyyteen vaikuttaa sellaisia musiikillisia piirteitä, joita ei ole ainakaan ekspli- 
siittisesti huomioitu aiemmassa muuntelun tutkimuksessa. Tiedonkäsittelymenetelmien kehittyminen puolestaan antaa mahdollisuuden käsitellä tehokkaasti laajempia aineistoja. Lisäksi muuntelun tutkimus on relevanttia tällä hetkellä, koska sillä on tiivis kytkentä viime vuosina hyvin aktiivisiin tutkimusaloihin: musiikillisen samankaltaisuuden ja musiikkitiedonhakumenetelmien tutkimukseen (Volk et. al 2012).

Tässä artikkelissa pyritään vastaamaan tilastollisen analyysin keinoin kysymykseen, voidaanko yksittäisen sävelen ominaisuuksien perusteella ennustaa, kuinka todennäköisesti sävelen korkeus toistuu samana muissa toisinnoissa tai mikä on todennäköisyys, että melodia muuttuu yksittäisen sävelen kohdalla. Lähtöoletuksena on, että muuntelun todennäköisyys on riippuvainen sävelen metrisestä painosta sekä sävelen sijainnista säkeessä ja melodiassa, kuten aiemmissa melodista muuntelua käsittelevissä tutkimuksissa on havaittu (Sundberg \& Lindblom 1976; Louhivuori 1988). Lisäksi oletetaan, että sävelen muuntumisen todennäköisyyden kanssa korreloivat sävelen ominaisuudet, joiden on todettu olevan yhteydessä melodian koettuun kompleksisuuteen ja muistamiseen.

Aineistona tutkimuksessa käytettiin toisintokokoelmaa, jossa on 1267 toisintoa 42:sta eri sävelmästä. Kokoelman toisintoluokitus validoitiin musiikin ammattilaisilla. Validoinnin perusteella eri ihmiset luokittelivat toisintoja erittäin samalla tavalla. Sävelen muuntumisen todennäköisyyttä mitattiin kahdella selitettävällä muuttujalla: sävelen muuntumisen todennäköisyydellä (todennäköisyys-mittari) ja sävelmän kohdan muuntumisen todennäköisyyttä mittaavalla entropia-mittarilla. Selittävinä muuttujina oli sävelen sijainti säkeistössä, sijainti säkeessä, metrinen paino, kesto, sävelluokka sekä edellinen ja seuraava intervalli.

Muuttujien analyysissä käytetään robustia regressioanalyysia sekä Spearmanin korrelaatiota ja osittaiskorrelaatiota. Analyysin perusteella kaikilla selittävillä muuttujilla, lukuun ottamatta seuraavaa intervallia, oli tilastollisesti erittäin merkitsevä yhteys sävelen korvautumisen ja sävelmän kohdan muuntumisen todennäköisyyteen. Käytetyt musiikilliset muuttujat selittivät yli 40 \% muuntelun todennäköisyyden vaihtelusta.

Tutkimuksen aiheena ollut sävelten korvautuminen ei suinkaan kata melodian muuntelua oraalisessa perinteessä kokonaisuudessaan, vaan melodiseen muunteluun kuuluvat myös rytmiset ja rakenteelliset muutokset. Sävelkorkeuksien muutokset ovat kuitenkin yksi keskeinen osa melodista muuntelua. 


\section{Muuntelun tutkimus}

Tässä yhteydessä ei ole mahdollista eikä tarkoituksenmukaista tehdä kattavaa katsausta muuntelun tutkimuksen oppihistoriasta: artikkelin ydin on aineiston tilastollisessa analyysissa. Käsittelen siis vain keskeisimpiä artikkelin aiheeseen välittömästi liittyviä kysymyksiä. Varhaisemmasta aihepiirin tutkimuksesta on tiivis yhteenveto Jukka Louhivuoren (1988: 16-18) väitöskirjassa Veisuun vaihtoehdot - Musiikillinen distribuutio ja kognitiiviset toiminnot. Anja Volk tutkimusryhmineen (2012) on puolestaan tehnyt ajantasaisen ja varsin monipuolisen katsauksen melodisen variaation ja melodisen samankaltaisuuden problematiikkaan artikkelissa, jossa pohditaan muuntelun mallintamisessa huomioitavia näkökulmia. Volkin tutkimusryhmän ja tämän tutkimuksen tavoitteet ovat samansuuntaiset, mutta tavoitteissa on kuitenkin selvä ero: Volk tutkimusryhmineen pyrkii 1) kehittämään tietokonemallin sävelmän sisäisten havaintopsykologisesti relevanttien muuntelevien jaksojen tunnistamiseksi ja 2) johtamaan samankaltaisuusmittarin, joka perustuu havaittuihin toistuviin jaksoihin. Tässä tutkimuksessa sen sijaan pyrin rakentamaan regressio-mallin, joka ennustaa muuntumisen todennäköisyyttä eri kohdissa melodiaa tai melodian eri sävelillä.

Viimeisen sadan vuoden aikana useat musiikintutkijat ovat pohtineet ja tehneet empiirisiä havaintoja siitä, missä kohden melodia tavallisesti muuntuu tai mitkä melodian ominaisuudet ovat pysyviä. Aiemmissa tutkimuksissa on päädytty erilaisiin painotuksiin ja jopa keskenään ristiriitaisiin käsityksiin. Eniten käsitykset tuntuvat vaihtelevan sävelmän ja säkeiden alkujen ja loppujen suhteen, joita toiset tutkijat ovat pitäneet erityisen stabiileina ja toiset taas erityisen herkkinä muutoksille (kts. Louhivuori 1988: 16-18). Vähemmän ristiriitaisuuksia käsityksissä näyttää olevan runkosävelten ja hajasävelten suhteen, joista runkosäveliä pidetään hajasäveliä stabiilimpina. Tosin jotkut tutkijat ovat huomauttaneet, että myös runkosävelet voivat muuttua (Louhivuori 1988: 249; Wiora 1941: 152). Tuoreimpia kysymystä käsitelleitä empiirisiä havaintoja on Taive Särgin ja Rytis Ambrazevičiuksen (Särg 2006; Särg \& Ambrazevičius 2007) virolaisien ja liettualaisien kansanlauluja käsittelevä tutkimus. He havaitsivat Thomassenin (1982) määrittelemän melodisen aksentin ja toisaalta tavujen painojen sekä melodian suunnan olevan yhteydessä muuntelun todennäköisyyteen. Volk ja van Kranen- 
burg (2012) puolestaan osoittivat, että toisintojen luokittelussa keskeisiä melodian piirteitä ovat säkeen ja koko sävelmän melodiakaarros ja rytmi sekä motiivit.

Eräänlaisena inspiraationa tälle tutkimukselle on ollut Johan Sundbergin ja Björn Lindblomin (1976) tutkimuksessansa Generative theories in language and music descriptions luoma teoreettinen malli, jonka tarkoitus oli generoida tyylinmukaisia toisintoja annetusta kehtolaulusta. Mallissaan he sovelsivat kielitieteessä kehitettyä generatiivista menetelmää. Toisintojen generointi perustui säännöstöön, jossa muuntumisen todennäköisyys on riippuvainen ns. prominenssi-säännöstä, jonka mukaan metrisillä painoilla ja musiikillisten jaksojen lopuissa muuntelu on epätodennäköisempää kuin muissa sävelmän kohdissa.

Louhivuoren (1988: 253) hengellisiä kansansävelmiä käsittelevässä väitöstutkimuksessa muuntelun määrän vaihtelu sävelmän eri kohdissa näytti noudattavan prominenssi-sääntöä. Louhivuoren mukaan sävelmien ja säkeiden loput olivat kaikkein yhtenäisimpiä ja säkeiden alut olivat yhtenäisempiä kuin keskikohdat (Louhivuori 1988: 284). Louhivuori (1988: 84) esitti myös hypoteesin, että yksinkertaiset formulat muuntuvat kompleksisempia epätodennäköisemmin. Väitöstutkimuksessaan hän ei kuitenkaan anna yksiselitteistä vastausta tähän hypoteesiin, vaan päätyy ajatukseen, että melodian kompleksisuutta ei voi selittää pelkästään musiikillisilla ominaisuuksilla vaan ne riippuvat havaitsijan oppimiskokemuksista (Louhivuori 1988: 145).

Vaikka koettuun kompleksisuuteen vaikuttavat oppimiskokemukset (kts. Eerola ym. 2006), melodian hahmottamista käsittelevissä tutkimuksissa on löydetty musiikillisia ominaisuuksia, jotka korreloivat koetun kompleksisuuden kanssa. Näitä ovat tonaalisuus, intervallien ryhmittyminen ja rytminen aktiivisuus ja synkopoivuus (Eerola \& North 2000; Narmour 1990; Krumhansl 1995; Krumhansl \& Kessler 1982; Clarke 1985; Povel \& Essens 1985; Conley 1981). Melodian kompleksisuuden voi nähdä myös musiikillisten odotusten täyttymisenä, jonka on todettu korreloivan siihen, kuinka hyvin melodia tunnistetaan tai muistetaan (Cuddy ym.1979; Schmuckler 1997). Voi kuvitella että, melodian muistamisen ja tunnistamisen suhteessa muunteluun on kaksi puolta: toisaalta esittäjä voi omilla variaatioillaan paikata sellaisia kohtia, joita ei muista ja toisaalta esittäjän voi olettaa varioivan mieluummin sellaisissa kohdissa, joiden muuntelu ei häiritse melodian tunnistamista niin paljon. Onkin havaittu, että ihmiset kiinnittävät melodian tunnistamisessa huomiota juuri niihin kohtiin, jotka näyttävät muun- 
tuvan epätodennäköisimmin eli metrisiin aksentteihin ja fraasien rajakohtiin (vrt. Boltz 1991; Boltz 1993; Schulkind ym. 2003; Sundberg \& Lindblom 1976; Louhivuori 1988: 253).

On siis perusteltua olettaa, että myös muut melodian tunnistamisen kanssa korreloivat piirteet ovat yhteydessä muuntelun todennäköisyyteen. Marilyn Boltz (1991) on havainnut, että melodioiden tunnistaminen helpottui, kun metrisissä aksenteissa ja fraasien rajakohdissa oli tonaalisesti merkitseviä säveliä eli toonikakolmisoinnun säveliä. Myös useat muut tutkimukset vahvistavat tonaalisuuden yhteyden melodian muistamiseen ja tunnistamiseen (Cuddy ym. 1981; Cuddy ym. 1979; DeWitt \& Crowder 1986; Dowling 1991; Schmuckler 1997). Pienien intervallien puolestaan on todettu toteuttavan melodisia odotuksia paremmin kuin suurien ja suuria intervalleja sisältävien melodioiden on todettu olevan vaikeita muistaa (Boltz 1991; Narmour 1990; Jones ym. 1978). Myös melodian nopeus vaikuttaa siihen kuinka hyvin melodia muistetaan (Jones ym. 1978) ja sävelmän tunnistamisen on havaittu osuvan keskimääräistä useammin suhteellisen pitkille sävelille (Schulkind ym. 2003).

Edellä esiteltyjen tutkimusten perusteella sävelen sijainnin säkeistössä ja säkeessä, metrisen paino, keston, sävelluokan sekä edellisen ja seuraavan intervallin voidaan olettaa vaikuttavan yksittäisen sävelkorkeuden tai sävelmän kohdan muuttumisen todennäköisyyteen. Näiden muuttujien tarkempaan määrittelyn palataan aineiston ja selitettävien muuttujien käsittelyn jälkeen.

\section{Aineisto}

Aineistona oli kokoamani vielä julkaisematon Juminkeko-toisintokokoelma, joka koostuu kuulonvaraisista nuotinnuksista valtaosaltaan Kuhmon musiikkiinstituutin kansanmusiikin tutkimus-, tallennus- ja elvytysprojektien kenttämatkoilla tehdyistä äänitteistä. Äänitykset on tehty Venäjän Karjalassa ja Kainuussa ja aineiston keruuseen on osallistunut useita tutkijoita ja opiskelijoita. Näiden lisäksi kokoelmaan on otettu toisintoja Suomen Kansan eSävelmiä -kokoelman Laulusävelmiä-jaksosta (52 kpl) ja Karjalaisia Kansanlauluja -kirjasarjasta (51 kpl) sekä yksi kappale kirjasta Femtio folkvisor från Åland (Bryggman \& Dreijer 1985). 
Toisintoja on tallennettu noin 150 laulajalta. Tarkkaa informanttien määrää ei tiedetä, koska Suomen Kansan Sävelmiä -kokoelmassa ja Karjalaisia kansansävelmiä -kirjasarjassa ei pääsääntöisesti ole ilmoitettu keneltä sävelmä on tallennettu. Äänitystilanteissa haastateltavia ei ole yleensä pyydetty laulamaan juuri tiettyjä lauluja, vaan he ovat saaneet vapaasti valita laulamansa kappaleet. Mikäli kahden tai useamman laulajan esityksessä on ollut moniäänisyyttä, olen nuotintanut vain ylimmän äänen. Äänitteitä ei ole tehty juuri tätä tutkimusta varten, vaan toisintokokoelma on koottu arkistoon kertyneestä materiaalista. Sävelmien valintaan on vaikuttanut ainoastaan se, kuinka paljon niistä on esityksiä Juminkeon äänitearkiston äänitallenteilla. Näin aineistoon ovat valikoituneet kaikkein tunnetuimmat sävelmät.

Nuotinnuksissa en pyrkinyt tarkkaan deskriptiiviseen transkriptioon, vaan tavoitteena on ollut riittävän tarkka preskriptiivinen runkonotaatio, jossa ilmenee standardisoidut sävelkorkeudet ja aika-arvot. Yksityiskohtaisten transkriptioiden tekeminen olisi vienyt huomattavasti enemmän aikaa, jolloin aineisto olisi jäänyt pienemmäksi. Myös muiden sävelmäkokoelmien nuotinnukset on pääosin tehty samalla tarkkuudella.

Kukin esitys nuotinnettiin kokonaan, minkä jälkeen nuotinnoksesta kopioitiin kukin säkeistö omaksi MIDI-tiedostokseen. Sävellajit ja rakenteet on standardisoitu niin, että kaikki toisinnot ovat C-duurissa tai c-mollissa ja kertaukset on poistettu. Aineiston verrattain suuri koko kompensoi kertauksien poistosta aiheutuvaa datan hävikkiä. Kertauksien sisällyttäminen aineistoon olisi aiheuttanut toisenlaisia metodisia ongelmia, koska käytetyn analyysimenetelmän ehtona on, että saman sävelmän eri toisinnot voidaan esittää samanpituisina melodiakaarroksina (sävelkorkeuksina ajanfunktiona). MIDI-formaatissa olevat tiedostot muunnettiin Matlab-ympäristössä toimivan MIDI-toolboxin NMAT-formaattiin, jota käytettiin analyysiin.

\section{Toisintoluokitus}

Kokoelman toisinnot on luokiteltu 42:een eri melodiaperheeseen. Melodiaperhe käsitetään joukoksi toisintoja, jotka ovat saman sävelmän eri ilmenemismuotoja (vrt. Nettl 2005: 114). Englannin kielessä on käytetty termiä tune-family (Ba- 
yard 1950; Nettl 2005: 114). Suoran käännöksen, sävelmäperheen, sijaan käytän käännöstä melodiaperhe, välttääkseni vaikutelman että yhteen ryhmään kuuluisi useita sävelmiä. Toisintojen luokitukseen ei ole olemassa yksiselitteisiä kriteerejä, sillä melodia voi muuttua missä kohden tahansa ja monella eri tavalla. Viimekädessä kyse on arviosta, että toisinnot ovat niin samankaltaisia, että on syytä uskoa niiden olevan toisintoja samasta sävelmästä. Melodioiden luokittelua helpotti se, että useimmiten saman melodiaperheen toisinnoissa myös sanat vastasivat toisiaan.

Aineiston eri melodiaperheissä on keskimäärin 30 toisintoa ja vaihteluväli on 9-9o toisintoa. Louhivuoren (1988: 269) tutkimuksessa toisinnot olivat sitä yhtenäisempiä, mitä enemmän niistä oli toisintoja, minkä Louhivuori tulkitsi johtuvan sävelmien yleisyydestä seuraavasta tuttuudesta. Melodiaperheiden koko huomioidaan myös tässä tutkimuksessa.

Puolet sävelmistä on tasajakoisia kahden säeparin mittaisia reki- ja piirilauluja. Lisäksi on yksi 2-säkeinen tasajakoinen sävelmä. Pääsääntöisesti tasajakoisena esitetystä Imatrankoski-sävelmästä on myös kaksi valssina esitettyä toisintoa. Kolmijakoisia sävelmiä on kaikkiaan 19 kappaletta. Valtaosa niistä on valsseja, joista yhdeksän on nelisäkeisiä ja kolme kahdeksansäkeisiä. Masurkkoja on viisi nelisäkeistä sävelmää ja yksi kaksisäkeinen sävelmä. Lisäksi kokoelmassa on yksi kaksisäkeinen kolmijakoinen aunuksenkarjalainen balladi ja yksi sekatahtilajinen sävelmä.

\begin{tabular}{|l|c|c|}
\hline \multicolumn{2}{|c|}{ Määrä } & Prosenttiosuus \\
\hline Tasajakoiset nelisäkeiset & 21 & $50,0 \%$ \\
\hline Valssit nelisäkeiset & 9 & $21,4 \%$ \\
\hline Masurkat nelisäkeiset & 5 & $11,9 \%$ \\
\hline Valssit kahdeksansäkeiset & 3 & $7,1 \%$ \\
\hline Tasajakoiset kaksisäkeiset & 1 & $2,4 \%$ \\
\hline Masurkat 2-säkeiset & 1 & $2,4 \%$ \\
\hline Muut kolmijakoiset 2-säkeiset & 1 & $2,4 \%$ \\
\hline Sekatahtilajiset nelisäkeiset & 1 & $2,4 \%$ \\
\hline Kaikkiaan & 42 & $100,0 \%$ \\
\hline
\end{tabular}

Taulukko 1: Erityyppisten sävelmien jakautuminen aineistossa. 


\section{Toisintoluokituksen validointi}

Koska toisintoluokitukselle ei ole yksiselitteisiä kriteerejä, toisintoluokitus validoitiin pienellä joukolla musiikin ammattilaisia. Tavoitteena oli tarkistaa luokittelevatko eri ihmiset melodioita samalla tavalla ja vastaavatko heidän luokituksensa Juminkeko-toisintokokoelman luokitusta sekä kuinka varmoja ihmiset ovat arvioistaan.

Validointi tehtiin kyselylomakkeella, jossa oli 15 esimerkkisävelmää ja 6o luokiteltavaa sävelmää, jotka olivat sattumanvaraisesti valittuja nuotinnuksia aineiston tasajakoisista kahdeksantahtisista sävelmäperheistä. Tavoitteena oli, että luokittelu perustuisi pelkästään nuottikuvan esittämään melodiaan. Tämän takia mitaltaan erilaiset sävelmät jätettiin kyselyn ulkopuolelle, jotta mitan poikkeavuudet eivät ohjaisi luokitusta eikä nuotinnuksissa ollut laulujen sanoja. 60 luokiteltavasta sävelmästä yhdeksän ei ollut kokoelman luokituksen mukaan minkään esimerkkisävelmän toisinto.

Kukin esimerkkisävelmä oli numeroitu numeroilla 1-15 ja vastaavasti luokiteltavat sävelmät numeroilla 1-6o. Tehtävänä oli merkitä 6o luokiteltavaa sävelmää sen esimerkkisävelmän numerolla, minkä toisinnosta kulloinkin oli kyse. Vastaajia pyydettiin valitsemaan vain yksi vaihtoehto. Jos vastaajan mielestä kyseessä ei ollut minkään esimerkkisävelmän toisinto, niin hän saattoi jättää kohdan tyhjäksi. Lisäksi pyydettiin arvioimaan viisiportaisella asteikolla kuinka varma on omasta arviostaan ( $1=$ en lainkaan varma ja $5=$ olen täysin varma).

Luokitustehtävän lisäksi vastaajilta kysyttiin ikää, sukupuolta, kuinka monta vuotta on harrastanut musiikkia, musiikkiopintoja (itseoppinut, kansalaisopisto tai vastaava, musiikkiopisto tai vastaava, korkea-aste) sekä musiikillista suuntautumista (jazz/rock/pop, kansanmusiikki, klassinen, muu).

Kyselyyn saatiin vastauksia neljä kappaletta. Vastaajista puolet oli naisia ja puolet miehiä. Musiikin harrastuksen he olivat aloittaneet 2-7-vuotiaina ja he olivat harrastaneet musiikkia 29-46 vuotta. Kaikki olivat opiskelleet musiikkia korkeakoulussa. Muusikkoina he luokittelivat itsensä jazz / rock / pop -muusikoiksi (2 hlö), kansanmuusikoiksi (1 hlö), klassinen (2 hlö), muu (2 hlö) (vaihtoehdoista saattoi valita useamman). Koehenkilöt eivät tunteneet Juminkekokokoelmaa entuudestaan, mutta tunsivat todennäköisesti osan sävelmistä, sillä kyselyssä oli muutama yleisesti tunnettu sävelmä. 
Arvioiden yksimielisyys määriteltiin psykologiassa yleisesti käytetyllä Fleissin kappa -mittarilla. Kappa on yksimielisyyskerroin, jossa on huomioitu sattuman vaikutus. Silloin kun arvioijien välillä ei ole suurempaa yksimielisyyttä kuin sattuman perusteella voidaan odottaa, kappa saa arvon o ja arvioiden ollessa täydellisen yksimielisiä kappa saa arvon 1 (Fleiss 1971).

Kaikki neljä arvioijaa olivat keskenään erittäin yksimielisiä (kappa $=0.86$; 95 $\%$ luottamusväli $0,85-0,87$ ). Arvioijien tekemät luokitukset vastasivat vielä paremmin kokoelman luokitusta. Kun laskettiin kappa kaikkien arvioijien ja kokoelman luokituksen välillä niin arvo oli o,89 (95 \% luottamusväli o,88-0,89). Kun enemmistön mielipidettä verrattiin kokoelman luokitukseen, kappa sai arvon 0,96 (95\% luottamusväli 0,95-0,98). Vain yhden sävelmän kahden toisinnon tapauksessa enemmistön mielipide poikkesi kokoelman luokituksesta. Näissäkin tapauksissa yksi arvioijista päätyi kokoelman luokituksen kanssa samaan arvioon.

Kyselyyn osallistuneiden määrä ei ollut suuri, mutta verrattain suuri kysymysten (sävelmien) ja kategorioiden (esimerkkisävelmien) määrä kompensoi koehenkilöiden pientä määrää. Sen ansiosta jo verrattain pienellä koehenkilömäärällä saatiin tulos, joka osoittaa lähes täydellistä yksimielisyyttä. Kun otetaan huomioon, että kyselyyn osallistuneiden henkilöiden musiikilliset taustat olivat erilaisia, näyttää siltä, että eri ihmiset luokittelevat melodiatoisintoja hyvin samankaltaisesti. Se että arvioiden samanlaisuus oli kaikkein voimakkain enemmistön ja kokoelman luokituksien välillä osoittaa, että yhden asiantuntevan arvioijan luokitusta voidaan pitää validina.

\section{Muuntelun määrän mittaaminen}

Tässä tutkimuksessa muuntelun todennäköisyyttä mitataan kahdella selittävällä muuttujalla: sävelen todennäköisyys sävelmän kohdassa (todennäköisyys-mittari) ja melodiaperheen säveljakauman entropia sävelmän kohdassa (entropiamittari). Todennäköisyys-mittari perustuu tilastolliseen todennäköisyyteen, eli todennäköisyys, että tietyssä kohdassa melodiaa oleva sävel muuttuu, määritellään käsillä olevan aineiston perusteella. Todennäköisyysmittarin arvot lasketaan kaavalla: 


$$
P_{i j}=\frac{n_{i j}}{N}
$$

jossa $P_{i j}$ on todennäköisyysarvo sävelkorkeuden $i$ esiintymiselle melodiaperheessä hetkellä $j, n_{i j}$ on sävelkorkeuksien $i$ määrä hetkellä $j$ ja $N$ on toisintojen määrä melodiaperheessä.

Entropia on epäjärjestyksen mittari. Se on peräisin termodynamiikasta, mutta sitä on sovellettu myös informaatioteoriassa mittaamaan viestin sisältämän informaation määrää ja musiikin tutkimuksessa kompleksisuuden mittarina (Snyder 1990: 122; Manzara ym.1992). Tässä tutkimuksessa entropialla mitataan kuinka paljon erilaisia säveliä melodiaperheessä on kullakin sävelen syttymishetkellä ja kuinka tasaisesti eri sävelet ovat jakautuneet. Muuntelua on vähän silloin kun melodiaperheessä sävelen syttymishetkellä on vähän eri sävelkorkeuksia ja sävelkorkeudet ovat kasautuneet yhdelle sävelelle. Tällöin entropia on lähellä nollaa. Päinvastaisessa tilanteessa, kun erilaisia mahdollisia sävelkorkeuksia on paljon eivätkä ne ole selvästi kasautuneet tietylle sävelelle, entropian arvo lähenee arvoa yksi.

Entropia-mittarin $H$ arvot on suhteellinen entropia hetkellä $j$, joka lasketaan:

$$
H_{j}=\frac{-\sum_{i=1}^{N} P_{i j} \log 2 P_{i j}}{\log N}
$$

jossa $P_{i j}$ on todennäköisyysarvo ja $N$ on mahdollisten sävelten määrä aineiston alimman ja korkeimman sävelen välillä.

Todennäköisyys- ja entropia-mittarit poikkeavat toisistaan siten, että todennäköisyys-mittari on sävelen ominaisuus, jolloin myös saman melodiaperheen samassa kohdassa olevat sävelet voivat saada erilaisia arvoja. Entropia-mittari sen sijaan on melodiaperheen kohdan ominaisuus, jolloin kaikki saman melodiaperheen samassa kohdassa syttyvät sävelet saavat saman arvon.

Kuva 1 kuvaa proseduuria mittareiden arvojen määrittelemiseksi. Mittareiden arvot määriteltiin toisintojen melodiakaarroksista, eli sävelkorkeuksista ajanfunktiona (MIDI-sävelet). Melodiakaarrosten resoluutioksi määriteltiin luku, jonka kerrannaisia kaikki sävelten syttymishetket olivat. Näin melodiakaarroksiin saatiin jokaista sävelen syttymishetkeä vastaavat näytteet. Jokaisen melodiaperheen toisintojen melodiakaarroksista luotiin taulukko, jossa toisintojen melodiakaarrokset olivat omissa sarakkeissaan. Taulukosta jokaiselle sävelen syttymishetkelle laskettiin todennäköisyys- ja entropia-mittarin arvot. Viimein 
molempien mittareiden arvot järjestettiin kahdeksi (todennäköisyys- ja entropiamittari) sarakkeeksi, jossa kukin rivi vastasi sävelen syttymishetkeä.

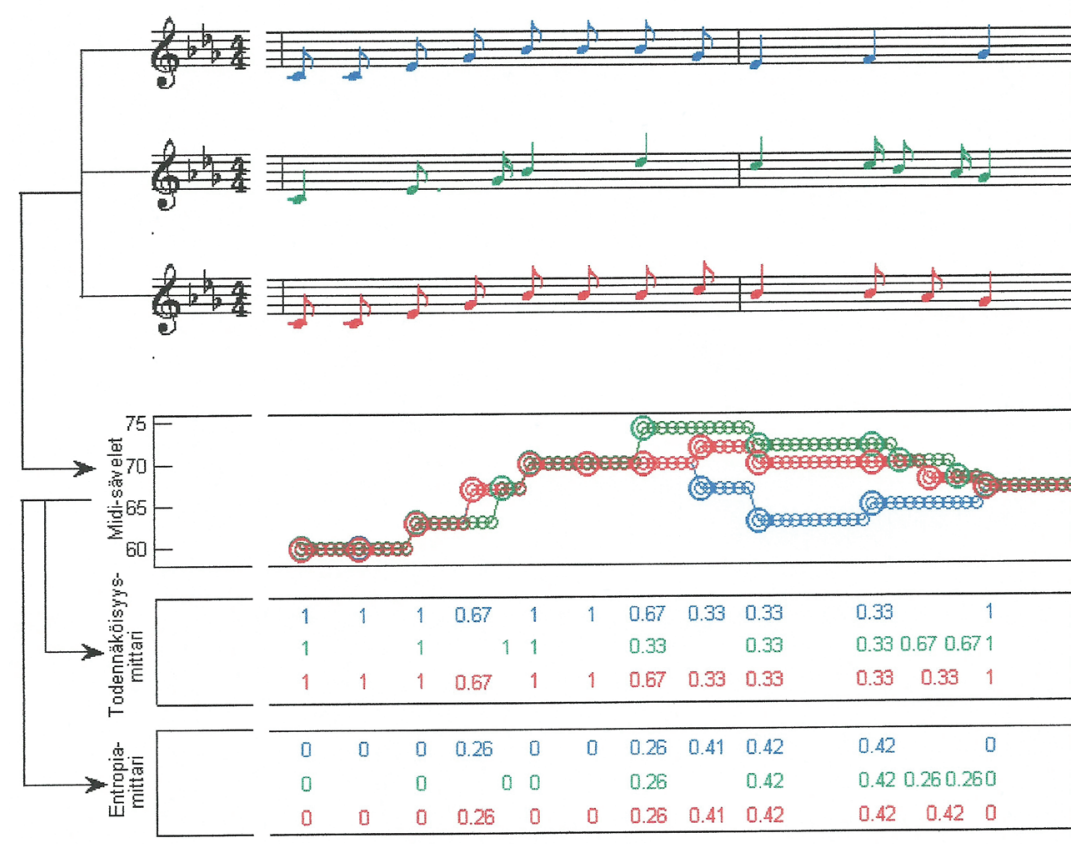

Kuva 1: Selittävien muuttujien koodaus: esimerkkitoisinnoista muodostetaan melodiakaarrokset, joista määritellään sävelen todennäköisyys ja melodiaperheen säveljakaumien entropia sävelen syttymishetkillä. Värikoodit ilmaisevat esimerkin toisintoja ja isot ympyrät sävelten syttymishetkiä melodiakaarroksissa.

Jakaumaltaan sekä todennäköisyys- että entropia-mittari ovat erittäin vinoja (todennäköisyysmittari: skewness $=-1.35$, entropia-mittari: skewness $=0.76)$. Molemmissa muuttujissa moodi on myös ääriarvo, minkä takia jakaumia ei voi muuntaa normaaliksi. Todennäköisyysmittarin tapauksessa moodi on maksimi eli yksi ja entropia-mittarin tapauksessa minimi eli nolla (35,5\% arvoista). Tämä osoittaa, että yli kolmasosassa sävelmäperheiden sävelistä ei ole muutosta sävelkorkeuksissa. 
Koska selittävät muuttujat perustuvat tilastolliseen todennäköisyyteen, mittarit ovat riippuvaisia melodiaperheen koosta: mitä vähemmän melodiaperheessä on toisintoja, sitä epätodennäköisempää on, että yksittäisen sävelen kohdalle sattuu muutos ja muuttumattomien sävelten osuus korostuu. Melodiaperheen toisintojen määrä vaikuttaa myös mittareiden asteikkojen tarkkuuteen. Melodiaperheen koon vaikutus mittareihin huomioidaan aineiston rajauksessa, josta tarkemmin menetelmäluvussa.

\section{Muuntelun määrän vaihtelua selittävät musiikilliset muuttujat}

Muuntelun määrän vaihtelua selittävät musiikilliset muuttujat voidaan jakaa metrisiin ja melodisiin muuttujiin. Mallissa huomioitavia sävelen metrisiä ominaisuuksia ovat sävelen sijainti säkeistössä, sijainti säkeessä, metrinen paino ja kesto. Melodisia muuttujia ovat puolestaan sävelluokka sekä säveltä edeltävä ja seuraava intervalli. Toisaalta muuttujat voidaan jakaa myös rakenteellisiin ja sävelkohtaisiin muuttujiin. Rakenteellisia ominaisuuksia ovat sävelen sijaintiin rakenteessa liittyvät muuttujat ja metrinen paino, jotka pysyvät vakioina saman melodiaperheen ja samankaltaista rakennetta noudattavien melodiaperheiden eri toisintojen vastaavissa rakenteellisissa kohdissa. Sävelkohtaisiin muuttujiin taas lukeutuvat sävelen kesto, sävelluokka- ja intervallimuuttujat, jotka voivat saada erilaisia arvoja saman melodiaperheen eri toisinnoissa.

RAKENTEELLISET MUUTTUJAT

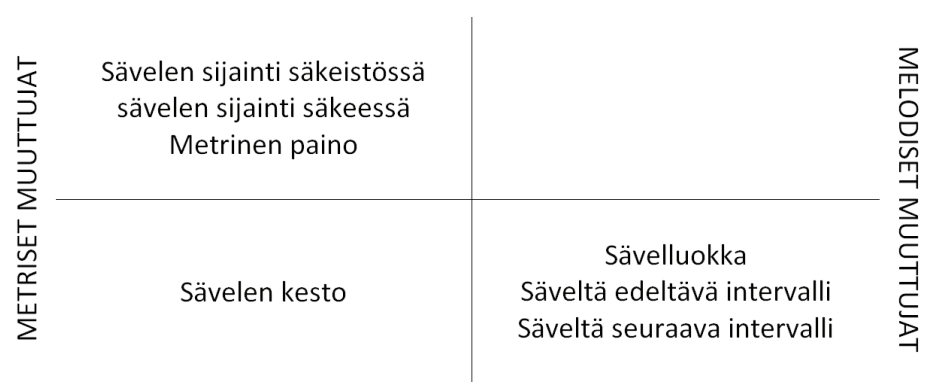

SÄVELKOHTAISET MUUTTUJAT

Kaavio 1: Muuntelun todennäköisyyttä selittävien muuttujien tyypittely. 
Metristen ja rakenteellisten muuttujien on aiemmissa tutkimuksissa todettu olevan yhteydessä melodian muunteluun, mutta melodisten ja sävelkohtaisten muuttujien yhteyttä muunteluun ei ole selvitetty (Louhivuori 1998: 284; Sundberg \& Lindblom 1979).

Sävelluokka- ja intervalli-muuttujilla on analogia Krumhanslin ja Kesslerin (1982) tonaaliseen hierarkiaan ja Narmourin (1990) implikaatio-realisaatio -mallin muuttujiin. Useimmilla näistä piirteistä onkin tilastollisesti merkitsevä yhteys muuntelun todennäköisyyteen. Voimakkain yhteys oli Krumhanslin ja Kesslerin tonaalisen hierarkian ja todennäköisyys-mittarin välillä ( $r h o=-0,22, p$ $<$ o,001, N = 15 547). Myös monilla implikaatio-realisaatio -mallin periaatteilla oli tilastollisesti erittäin merkitsevä yhteys muuntelun mittareihin (registral return, intervallic difference, closure), kun vähintään järjestysasteikollisissa piirteissä muuttujien välinen yhteys määriteltiin Spearmanin järjestyskorrelaatiolla ja luokitteluasteikollisissa Kruskal-Wallisin testillä. Mallissa päädyttiin kuitenkin käyttämään aineistopohjaisia muuttujia, koska niillä saatiin parempia tuloksia ja niistä saadaan yksityiskohtaisempaa tietoa muuttujien ja muuntelun välisen yhteyden luonteesta. Toisin kuin Särgin ja Ambrazevičiuksen (Särg 2006; Särg \& Ambrazevičius 2007) virolaisia ja liettualaisia lauluja käsittelevissä tutkimuksissa tämän tutkimuksen aineistossa melodisella aksentilla (Thomassen 1982) ei ollut korrelaatiota muuntelun todennäköisyyteen.

\section{Sävelen sijainti säkeistössä ja säkeessä}

Muuntelun suhdetta sävelen sijaintiin säkeistössä ja säkeessä kuvaavan mallin määrittelyä varten määritellään sävelten syttymishetkien suhteelliset sijainnit musiikillisissa jaksoissa. Ne lasketaan:

$$
\begin{aligned}
& A=\left\{x_{1}, \ldots, x_{n}\right\} \\
& A_{1}=\left(A-x_{1}\right) / x_{n}
\end{aligned}
$$

jossa $A$ on syttymishetket musiikillisessa jaksossa ja $A_{1}$ on sävelten suhteellinen sijainti musiikillisessa jaksossa. 
Muuntelun vaihtelua musiikillisissa jaksoissa kuvaava malli määritellään sovittamalla entropia-mittari- ja sävelen suhteellinen sijainti -dataan $n$ :nen asteen polynomi pienimmän neliösumman menetelmällä. Jos $x$ on sävelen sijainti musiikillisessa jaksossa ja $y$ on entropia-mittari, niin entropian-mittarin vaihtelua musiikillisessa jaksossa kuvaava n:nen asteen polynomi on:

$$
p(x)=p_{1} x^{n}+p_{2} x^{n-1}+\ldots+p_{n} x+p_{n+1}
$$

Korkea-asteisemmat polynomit ennustivat muunteluun vaihtelua, jota on vaikea perustella juuri sävelen sijainnista ao. musiikillisessa jaksosta johtuvaksi. Korkeaasteisissa polynomeissa on myös suurempi ylisovittumisen riski, jolloin käyrä sopii hyvin opetusaineistoon, mutta ei välttämättä uuteen aineistoon. Tämän takia n:n maksimiarvoksi asetettiin 4. Optimaaliset asteluvut säkeistö- ja säemalleille määriteltiin maksimoimalla opetusaineistolla tehdyn regressiomallin selitysaste.

Säkeistön ja säkeen lisäksi olisi mahdollista käyttää myös muun tasoisia musiikillisia jaksoja, kuten säepari tai iskuala. Säe ja säkeistö valittiin, koska niiden osuminen päällekkäin keskenään tai muiden selittävien muuttujien kanssa on epätodennäköisintä. Esimerkiksi säkeistö voi muodostua yhdestä säeparista (useammin kuin yhdestä säkeestä). Toisaalta alemman tason jaksot ovat jo lähellä metrisiä painoja, joita käsitellään seuraavaksi.

\section{Metriset painot}

Sävelten metriset painot on määritelty manuaalisesti arvoilla 1-3, niin että arvo 3 vastaa pääiskua, 2 sivuiskua ja 1 hierarkkisesti tätä alemman tason iskuja. Kolmiportaisella koodauksella muuntelun todennäköisyyden ja metrisen painon välinen riippuvuus oli lineaarinen, toisin kuin sitä useampiportaisilla koodauksilla (kts. kuva 2). Heikoimpien metristen painojen välillä ei enää ollut tilastollisesti merkitsevää eroa muuntelun todennäköisyydessä. Kolmiportaista luokittelua tuki myös se, että alimpia tasoja olevia iskuja oli huomattavasti vähemmän kuin ylemmän tason iskuja. 


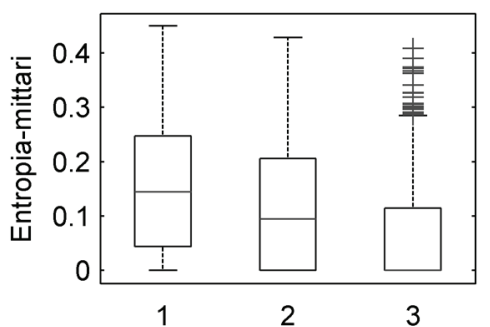

Metrinen paino 3-portaisella asteikolla

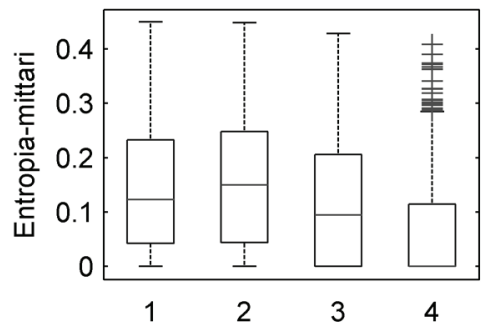

Metrinen paino 4-portaisella asteikolla

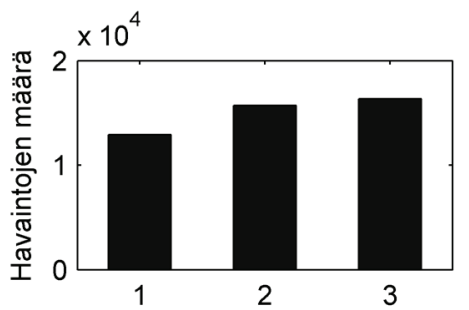

Metrinen paino 3-portaisella asteikolla

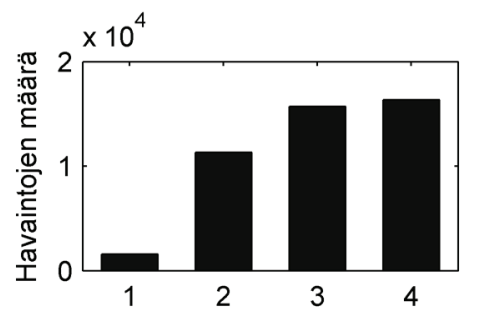

Metrinen paino 3-portaisella asteikolla

Kuva 2: Metrisen painon 3- ja 4-portaisen koodauksen vertailu. Ylärivin boxplot-kuvissa entropia-mittarin mediaanit, 25. ja 75. persentiilit ja vaihteluvälit. Alarivillä metristen painojen histogrammit.

\section{Sävelten kestot}

Sävelten kesto -muuttujan arvot määritellään jakamalla kunkin toisinnon sävelten kestot kyseisen toisinnon sävelten kestojen maksimilla, jolloin saadaan sävelten suhteelliset kestot. Suhteellisiin kestoihin päädyttiin, koska eri toisinnoissa esiintyvät vastaavat aika-arvot eivät ole yhteismitallisia, sillä tempot vaihtelevat ja sekuntimääräisiä sävelten kestoja ei ole määritelty. 


\section{Sävelmuuttujat}

Sävelmuuttujien arvot perustuvat aineistoon. Ne määritellään todennäköisyysmittarin perusteella, koska se on sävelen ominaisuus toisin kuin entropia-mittari, joka melodiaperheen rakenteen ominaisuus.

Sävelluokkamuuttuja perustuu useissa tutkimuksissa vahvistettuun ilmiöön, että toiset sävelluokat (sävelluokka on termi, jossa huomioidaan sävelen sävelyys, mutta ei oktaavialaa) koetaan paremmin tonaaliseen kontekstiin sopiviksi kuin toiset (kts. mm. Krumhansl 1990: 18-19). Parhaiten tonaaliseen kontekstiin sopiviksi koetaan tavallisesti I-asteen kolmisoinnun sävelluokat, muut diatoniset sävelet koetaan kohtuullisen hyvin sopiviksi ja huonoiten sopiviksi koetaan asteikkoon kuulumattomat sävelet. Tonaalisessa musiikissa sävelluokilla on siis hierarkkinen järjestys. Tätä ilmiötä kutsutaan tonaaliseksi hierarkiaksi. Lähtöoletus tässä tutkimuksessa on, että eri sävelluokkien korvautumisen todennäköisyys noudattaa samankaltaista hierarkiaa.

Sävelluokkamuuttuja määritellään erikseen duuri- ja mollisävelmille, koska sävelluokkien korvautumisen oletetaan olevan riippuvainen tonaalisesta kontekstista. Sävelluokkamuuttujan arvot on yhtä kuin tonaalisessa kontekstissaan olevien sävelluokkien $x$ todennäköisyysmuuttuja-arvojen mediaani. Havaintojen pienen määrän takia asteikkoon kuulumattomat sävelluokat on yhtä kuin kaikkien asteikkoon kuulumattomien sävelluokkien todennäköisyysmuuttujan-arvojen mediaani. Mollisävellajisissa sävelmissä asteikkoon kuuluviksi katsottiin sekä harmonisen että luonnollisen mollin mukainen seitsemäs aste. Ylennetty kuudes aste oli harvinainen ( $14 \mathrm{kpl}$ ), joten se katsottiin asteikkoon kuulumattomaksi.

Edellinen ja seuraava intervalli -muuttujien tapauksessa täsmällisempi nimitys olisi edellisen ja seuraavan intervallin koko -muuttujat, sillä arvot on määritelty peräkkäisten sävelten erotuksen itseisarvon perusteella. Yksinkertaisuuden vuoksi käytän kuitenkin tässä yhteydessä intervalli-nimitystä intervallin koon sijaan. Intervallien suunta ei näyttänyt juurikaan vaikuttavan muuntelun todennäköisyyden vaihteluun, joten itseisarvojen käyttöä voi pitää perusteltuna, etenkin kun sen ansiosta intervalleille saadaan suurempi edustus.

Ajatus intervallien käytöstä selittävänä muuttujana perustuu Narmourin (1990) implikaatio-realisaatio -malliin. Siitä poiketen tässä mallissa huomioidaan edellisen intervallin lisäksi seuraavat intervallit. Tätä voi pitää perusteltuna tässä 
tapauksessa, kun on kyse melodian hahmottamisesta esittämisen, ei kuulemisen, aikana, jolloin esittäjällä on tarkempi käsitys melodian jatkumisesta. Tämän takia voi olettaa, että musiikilliset tapahtumat joita kohden esittäjä on etenemässä ohjaavat häntä yhtälailla kuin jo menneet tapahtumat.

Edellinen ja seuraava intervalli -muuttujien koodaus perustuu samanlaiseen logiikkaan kuin sävelluokkamuuttujan: kutakin intervallia vastaava sävel uudelleen koodataan intervallia vastaavalla sävelluokkamittarin mediaanilla.

Aineistoon perustuvien sävelen sijainti säkeessä- ja säkeistössä- sekä sävelluokka- ja intervalli-muuttujien arvot raportoidaan Tulokset-luvussa.

\section{Menetelmä}

Muuntelun ja musiikillisten muuttujin välistä yhteyttä kuvaava malli tehtiin robustilla regressioanalyysillä. Regressioanalyysi on menetelmä, jossa useilla selittävillä muuttujilla selitetään yhden selitettävän muuttujan vaihtelua. Regressioanalyysillä voi myös luoda mallin, jolla voi selittävien muuttujien perusteella ennustaa selittävän muuttujan arvoja uudella datalla. Regressioanalyysin ehtoihin kuuluu virhetermien normaali jakautuminen ja varianssien yhtä suuruus. Nämä ehdot eivät täyty aineistossa, minkä takia käytettiin robustia regressioanalyysiä, joka soveltuu dataan, jossa virhetermit ovat poikkeavasti jakautuneita. Robusti regressioanalyysi tehtiin Matlabin Statistics Toolboxin robustfit -funktiolla, jossa käytetään sen oletuspainotus-funktiota (bisquare). Robustin regressiomallin seli-

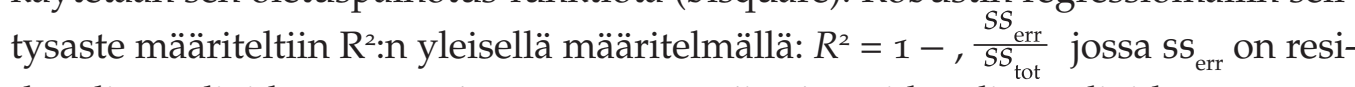
duaalien neliöiden summa ja $s_{\text {tot }}$ on muuttujien ja residuaalien neliöiden summa ${ }^{1}$. Mahdollista selitysastetta on käytetty estimaattina $R^{2}$ :n sijaan, koska Pearsonin korrelaatioista laskettu $\mathrm{R}^{2}$ edellyttää muuttujien normaalia jakautumista.

Vaikka menetelmä ei edellytä muuttujien normaalia jakautumista, niin parhaaseen malliin päästiin tekemällä selitettäville muuttujille muunnos, jolla minimoitiin jakauman vinous. Muunnos tehtiin potenssiin korotuksella. Regressioanalyysissä oletetaan, että selittävät muuttujat ovat lineaarisessa suhteessa selitettävään muuttujaan. Tämän takia selittävien muuttujien muunnoksessa ha-

\footnotetext{
1 kts. http://www.mathworks.se/support/solutions/en/data/ $1-\mathrm{CMABGO} /$ index.html? product= ST\&solution=1-CMABGO
} 
ettiin muunnosparametrille arvo, jolla lineaarisuusehto täyttyi parhaiten. Tämä tehtiin maksimoimalla Pearsonin korrelaatiokerroin.

Muuntumisen todennäköisyys -dataan perustuvat selittävät muuttujat opetettiin opetusaineistolla siten kuin Sävelen sijainti säkeistössä ja säkeessä -luvussa kuvattiin ja testattiin testiaineistolla. Datan tehokkaan hyödyntämisen ja tulosten yleistettävyyden parantamiseksi analyysissä käytettiin ristiinvalidointia, jolloin jokainen datapiste on vuorollaan opetus- ja testiaineistona. Näin on mahdollista arvioida kuinka vakioina eri muuttujien arvot erilaisilla aineistoilla opetettaessa pysyvät. Lopullista mallia varten arvot määriteltiin mahdollisimman edustavalla osa-aineistolla.

Ristiinvalidoinnissa aineisto jaetaan N:ään (mahdollisimman) yhtä suureen osaan, joista kutakin vuorollaan käytetään testaukseen, kun loput valitaan opetusaineistoksi. Riippuen N:än arvosta puhutaan esimerkiksi 1o-kertaisesta tai 3-kertaisesta ristiinvalidoinnista.

Datan luonteen takia tässä tutkimuksessa käytetty ristiinvalidointi poikkesi tavallisesta käytännöstä. Tavallisesti datapisteet jaetaan sattumanvaraisesti eri osiin. Tällä aineistolla tuon kaltainen satunnaistaminen olisi tuottanut osa-aineistoja, joihin olisi kuulunut samojen melodiaperheiden dataa. Tämä olisi antanut epärealistisen hyvän kuvan mallin yleistettävyydestä, koska etenkin entropianmittarin vaihtelu on melodiaperheiden eri toisinnoissa käytännössä samanlaista. Tämän takia aineisto ositettiin melodiaperheittäin niin, että kuhunkin osaan tuli yhtä monta melodiaperhettä, jolloin eri osien datapisteiden määrissä oli eroja sävelmien pituuksien erojen takia. Myöskään tavallisesti käytetty 10-kertainen ristiinvalidointi, ei osoittautunut tällä aineistolla hyväksi menettelytavaksi. Karsitulla aineistolla se olisi johtanut tilanteeseen, jossa jotkut testiaineistot olisivat koostuneet yhdestä melodiaperheestä. Tällöin olisi saatu hyvin vaihtelevia tuloksia, joita keskiarvoistaminen ei olisi tasannut niin, että olisi saatu realistinen kuva mallin suorituskyvystä. Sopivaksi ratkaisuksi osoittautui 3-kertainen ristiinvalidointi. Sillä saatiin vielä tarpeeksi suuria opetusaineistoja hyvän yleistettävyyden saavuttamiseksi ja toisaalta jokaisessa testiaineistossa oli useampia melodiaperheitä, jolloin erot eri aineistoilla saaduissa tuloksissa olivat pieniä.

Aineiston karsintaa tehtiin kahdella kriteerillä: melodiaperhenäytteen koko ja muuntelun määrä melodiaperheessä. Melodiaperheen kokoon perustuvaa karsintaa tehtiin, koska toisintojen määrä vaikuttaa entropia- ja todennäköisyys-mittareiden arvoihin. Pääasiallinen mekanismi tämän takana on, että toisintojen määrän kasvaessa todennäköisyys muuntelun esiintymiselle melodian eri kohdissa 
kasvaa. Tällöin voidaan myös olettaa muuntelun todennäköisyyteen korreloivien musiikillisten piirteiden nousevan voimakkaammin esiin. Toisaalta vähäinen toisintojen määrä huonontaa mittaustarkkuutta selittävissä muuttujissa, koska pienillä havaintomäärillä yksittäisellä poikkeavalla sävelellä on voimakkaampi vaikutus entropiaan ja muuttumattomuuden todennäköisyyteen kuin suuremmilla.

Muuntelun määrään perustuvaa karsintaa tehtiin kahdesta syystä. Ensinnäkin melodiaperheet, joissa oli poikkeuksellisen vähän muuntelua, olivat ongelmallisia, koska ne lisäsivät selitettävien muuttujien vinoutta. Toisaalta melodiaperheissä joissa oli poikkeuksellisen paljon muuntelua, oli toisintoja jotka poikkesivat muista toisinnoista niin paljon, että voi epäillä suurten erojen johtuvan esimerkiksi siitä, että laulajalla on ollut ongelmia melodiahahmon muistiin palauttamisessa.

Muuntelun määrään perustuen karsittiin melodiaperheet, joiden entropianmittarin keskiarvo poikkesi kaikkien melodiaperheiden entropia-mittarin keskiarvosta $(0,11)$ enemmän kuin keskihajonnan $(0,05)$ verran. Toisintojen määrään perustuvassa karsinnassa tavoitteena oli määritellä aineisto, jolla saadaan paras yleistettävyys. Siksi raja-arvoksi toisintojen määrässä valittiin sen kokoinen aineisto, jolla ristiinvalidointi tuotti parhaan tuloksen.

Sekä melodiaperhenäytteen kokoon että muuntelun määrään perustuva karsinta pienensi jakaumien vinoutta muuntelun mittareissa, koska muuntumattomien sävelten osuus pieneni. Datan hävikki ei muodostunut ongelmaksi, sillä regressioanalyysin oletuksena oleva 20 havaintoa selittävää muuttujaa kohden täyttyi jopa yhtä melodiaperhettä käytettäessä. Tällöin datapisteiden määrä oli yli 400 datapistettä selittävää muuttujaa kohden.

Estimaatti mallin suoristuskyvystä saadaan laskemalla ristiinvalidoinnissa eri testiaineistolla saatujen suorituskykysuureiden keskiarvo. Tässä tapauksessa mallin suorituskykyä arvioidaan mallin antamien arvojen Spearmanin järjestyskorrelaatiolla muuntelun mittareihin (entropia- ja todennäköisyysmittari). Eiparametrinen Spearmanin järjestyskorrelaatio soveltuu kyseisen aineiston korrelaatiokertoimeksi Pearsonin korrelaatiokerrointa paremmin, koska aineisto ei ole normaalisti jakautunut.

Yksittäisten selittävien muuttujien yhteys muuntelun todennäköisyyteen estimoidaan Spearmanin järjestyskorrelaatiolla ja osittaiskorrelaatiolla, joka niin ikään lasketaan Spearmanin järjestyskorrelaatiolle. Osittaiskorrelaatiossa vakioidaan muut muuttujat, jolloin voidaan arvioida paremmin mikä on ilmiöiden todellinen yhteys. Tässä tutkimuksessa myös osittaiskorrelaatioissa käytetään 
edellä kuvattua ristiinvalidointia, jolloin opetus- ja testiaineistona ei käytetä samaa dataa. Näin voidaan varmistua tulosten yleistettävyydestä.

\section{Tulokset}

Ristiinvalidoinnin perusteella optimaaliseksi analyysiaineiston kooksi osoittautui kahdeksan suurinta melodiaperhenäytettä, jolloin kussakin melodiaperhenäytteessä oli vähintään 37 toisintoa. Tämän kokoisella osa-aineistolla saatiin testiaineistoilla paras korrelaatioiden keskiarvo mallin tuottamien arvojen ja selittävien muuttujien välillä (entropia-mittari: rho $=0,55, \mathrm{p}<0,0001$, todennäköisyysmittari: rho $=0,50, p<0,0001, N=15547$ ). Seuraavat tulokset perustuvat tällä osa-aineistolla saatuihin ristiinvalidoinnin tuloksiin. Muilla osa-aineistoilla saatuihin tuloksiin viitataan tarvittaessa esimerkiksi, kun ne ovat ristiriidassa varsinaisella aineistolla saatujen tulosten kanssa.

Voimakkain yhteys muunteluun oli yksiselitteisesti sävelen kestolla. Sen korrelaatioiden ja osittaiskorrelaatioiden keskiarvot olivat suurimmat molempiin muuntelun mittareihin kaikilla osa-aineistoilla (kts. taulukko 2). Osittaiskorrelaatioiden keskiarvon perusteella sävelen sijainnilla säkeistössä oli toiseksi voimakkain yhteys muunteluun, vaikka korrelaatioiden keskiarvot olivatkin suurempia metrisellä painolla, kun muiden muuttujien vaikutusta ei otettu huomioon.

Sävelmittareiden keskinäinen järjestys ei ollut yksiselitteinen. Taulukossa 2 nähdään, että heikoin osittaiskorrelaatio entropia-mittariin oli sävelluokkamittarilla, kun käytettiin optimaalista osa-aineistoa. Kuitenkin suurimmalla osalla osa-aineistoista sävelluokka-mittarin yhteys muunteluun oli sävelmuuttujista voimakkain, mikä näkyy eri osa-aineistoilla saatujen tulosten keskiarvossa. Eri osa-aineistoilla saatujen tulosten keskiarvosta nähdään myös, että edellisen intervallin kuten myös sävelen sijainnin säkeistössä korrelaation keskiarvot muuntelun mittareihin olivat pääsääntöisesti hyvin heikkoja.

Musiikillisten muuttujien korrelaatiot olivat pääsääntöisesti tilastollisesti erittäin merkitseviä $(\mathrm{p}<0,001)$. Ainoastaan edellisen intervallin ja sävelen sijainnin säkeistössä korrelaatioiden merkitsevyystaso vaihteli riippuen käytetystä osaaineistosta $(\mathrm{p}>0,5-\mathrm{p}<0,01)$. 


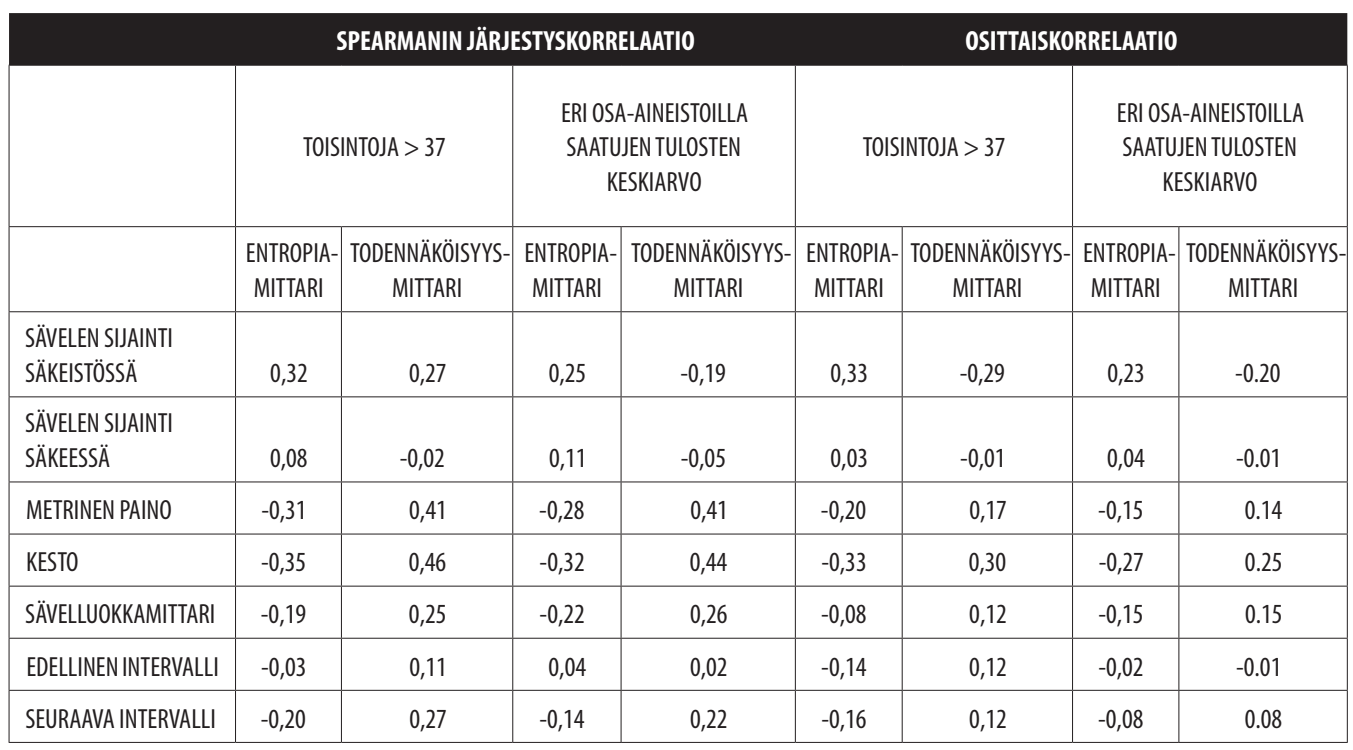

Taulukko 2: Musiikillisten muuttujien korrelaatioiden keskiarvot muuntelun mittareihin, kun ristiinvalidoinnissa on käytetty osa-aineistoa, jossa jokaisessa melodiaperheessä on vähintään 37 toisintoa ( $\mathrm{N}=15547)$. Korrelaatiot on mitattu Spearmanin järjestyskorrelaatiolla.

\section{Opetetut selittävät muuttujat}

Edellä esiteltyjen tulosten perusteella voidaan arvioida tässä tutkimuksessa käytetyillä menetelmillä estimoidun mallin kykyä ennustaa muuntelun todennäköisyyttä. Seuraavassa esitellään malli, joka aineiston perusteella näyttäisi käytetyillä parametreillä ennustavan parhaiten muuntelua. Mallin opetuksessa on käytetty koko osa-aineistoa, jossa on vähintään 37 toisintoa jokaisessa melodiaperheessä.

Muuntelun vaihtelua musiikillisissa jaksoissa kuvaavista malleista (kts. kuva 3) nähdään, että musiikillisten jaksojen lopussa muuntelun määrässä on prominenssi-teorian mukaisen vähenevä trendi. Löydös, jota prominenssi-teoria ei ennusta, on muuntelun määrän asteittainen nousu säkeistön aikana ennen aivan säkeistön lopussa tapahtuvaa jyrkkää laskua. Ristiinvalidoinnissa parhaaksi osoittautuneella osa-aineistolla, entropian suhdetta sekä säkeeseen että säkeistöön parhaiten mallissa kuvasivat 2. asteen yhtälöt (kts. kuva 3). 

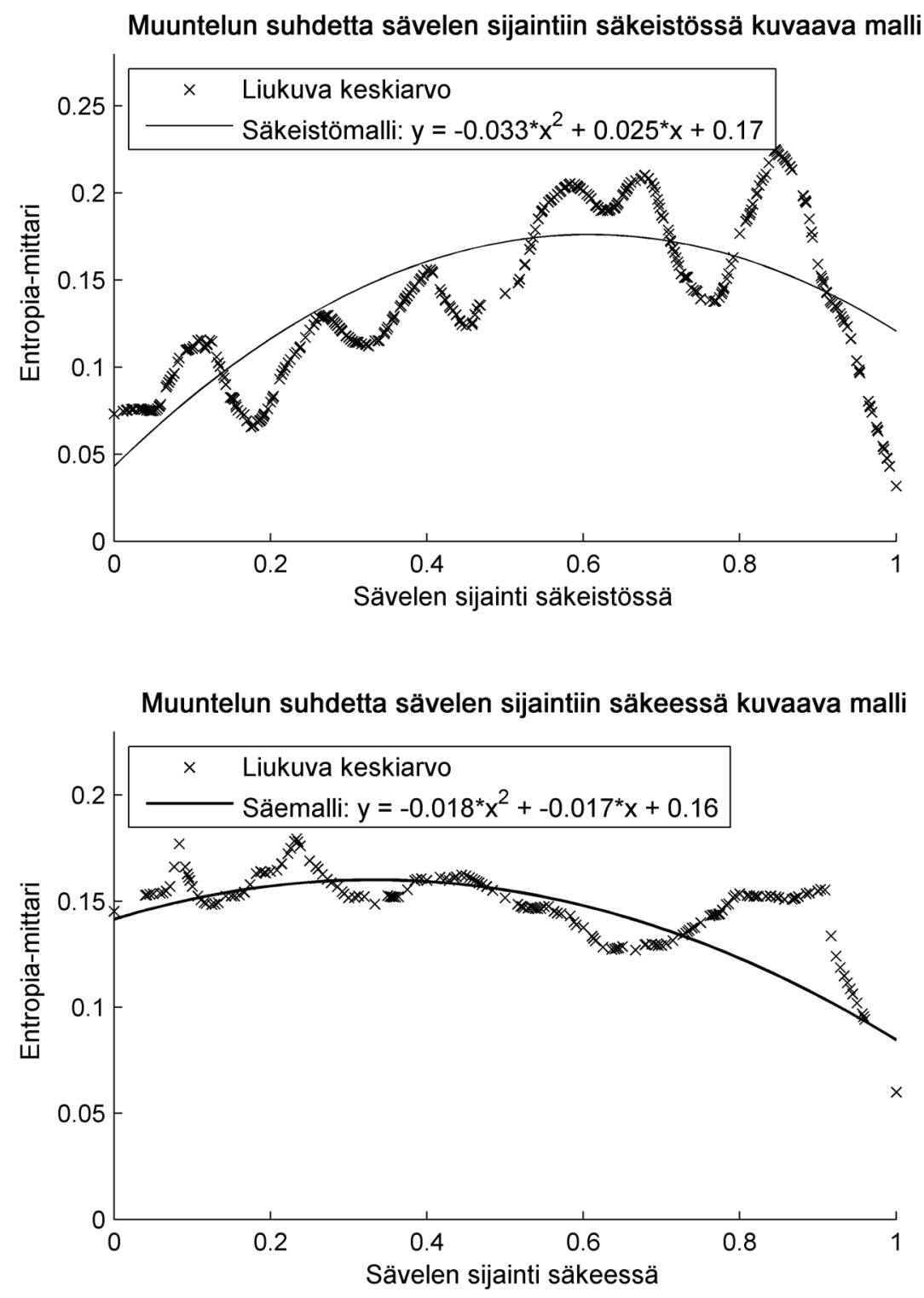

Kuva 3: Entropian vaihtelua musiikillisissa jaksoissa kuvaavat mallit ja liukuva keskiarvo. Malleissa y on ennustettu entropia ja x sävelen suhteellinen sijainti musiikillisessa jaksossa. 
Sävelen sijainti säkeistössä korreloi verrattain heikosti selittäviin muuttujiin. Tämän takia testattiin, saadaanko parempia tuloksia, jos esi- ja jälkisäkeille sekä/tai pääiskulla ja kohotahdilla alkaville säkeille opetetaan omat mallit. Erityyppiset säkeet poikkesivat toisistaan: jälkisäkeissä entropia laski nopeammin kuin esisäkeissä ja kohotahdilla alkavissa säkeissä oli entropia aivan alussa huomattavasti korkeammalla kuin muualla säkeessä päinvastoin kuin pääiskulla alkavissa säkeissä. Erityyppisten säkeiden huomioiminen erikseen ei kuitenkaan parantanut tuloksia.

Oletuksen mukaisesti sävelluokan muuttumisen todennäköisyys näyttää olevan riippuvainen sävelen tonaalisesta painosta: tonaalisesti painavimpien sävelasteiden, toonikan ja dominantin, korvautuminen toisella on kaikkein epätodennäköisintä ja asteikkoon kuulumattomien sävelten korvautuminen on kaikkein todennäköisintä (kts. kuva 4). Määriteltyjen muuttumattomuuden todennäköisyyden arvojen ja Krumhansl \& Kesslerin sävellaji-profiilien välillä onkin huomattava korrelaatio (duuri-sävellajissa $r=0,87$ ja molli-sävellajissa $r=0,77$ ). Sekä duuri- että mollisävellajeissa huomattavin ero muuttumattomuuden todennäköisyydessä verrattuna tonaaliseen hierarkiaan on toisen asteen huomattavasti kolmatta astetta suurempi arvo.

Riippumatta osa-aineiston koosta sävelluokkamuuttujien profiilit pysyivät varsin samankaltaisina etenkin duuri-sävellajissa: erikokoisiin aineistoihin perustuvien profiilien väliset korrelaatiot olivat vähintään o,93 duuri-sävellajeissa. Molli-sävellajeissa korrelaatiot jäivät pienemmiksi (minimi 0,76). Molli-profiileissa huomattavin ero suuriin ja pieniin aineistoihin perustuvien arvojen välillä oli eri diatonisten sävelten saamien arvojen erojen korostuminen pienemmillä aineistoilla. Tämä havainto tukee oletusta, että rajattaessa aineistosta pienet melodiaperheet, muuntelua selittävät ilmiöt nousevat voimakkaammin esille.

Intervallimuuttujien määritellyt arvot eivät pysyneet yhtä vakioina kuin sävelluokka-muuttujan (kts. kuva 5). Erikokoisilla aineistoilla määriteltyjen arvojen vertailussa seuraava intervalli -muuttujien korrelaatiot vaihtelivat 0,71 ja 0,99 välillä ja edellinen intervalli -muuttujien korrelaatiot 0,58 ja 0,99 välillä. Teoreettisesti intervalli-muuttujien arvot eivät ole kaikilta osin niin ymmärrettäviä kuin sävelluokka-muuttuja. Ongelmallisinta on perustella suuren sekstin korkeata arvoa, kun muut yhtä korkeita arvoja saavat intervallit ovat puhtaita tai edellinen intervalli -muuttujan tapauksessa verrattain pieniä. Yksi mahdollinen selitys on, että esiintyessään suuri seksti on tavallisesti tonaalisesti vahvojen viidennen ja 

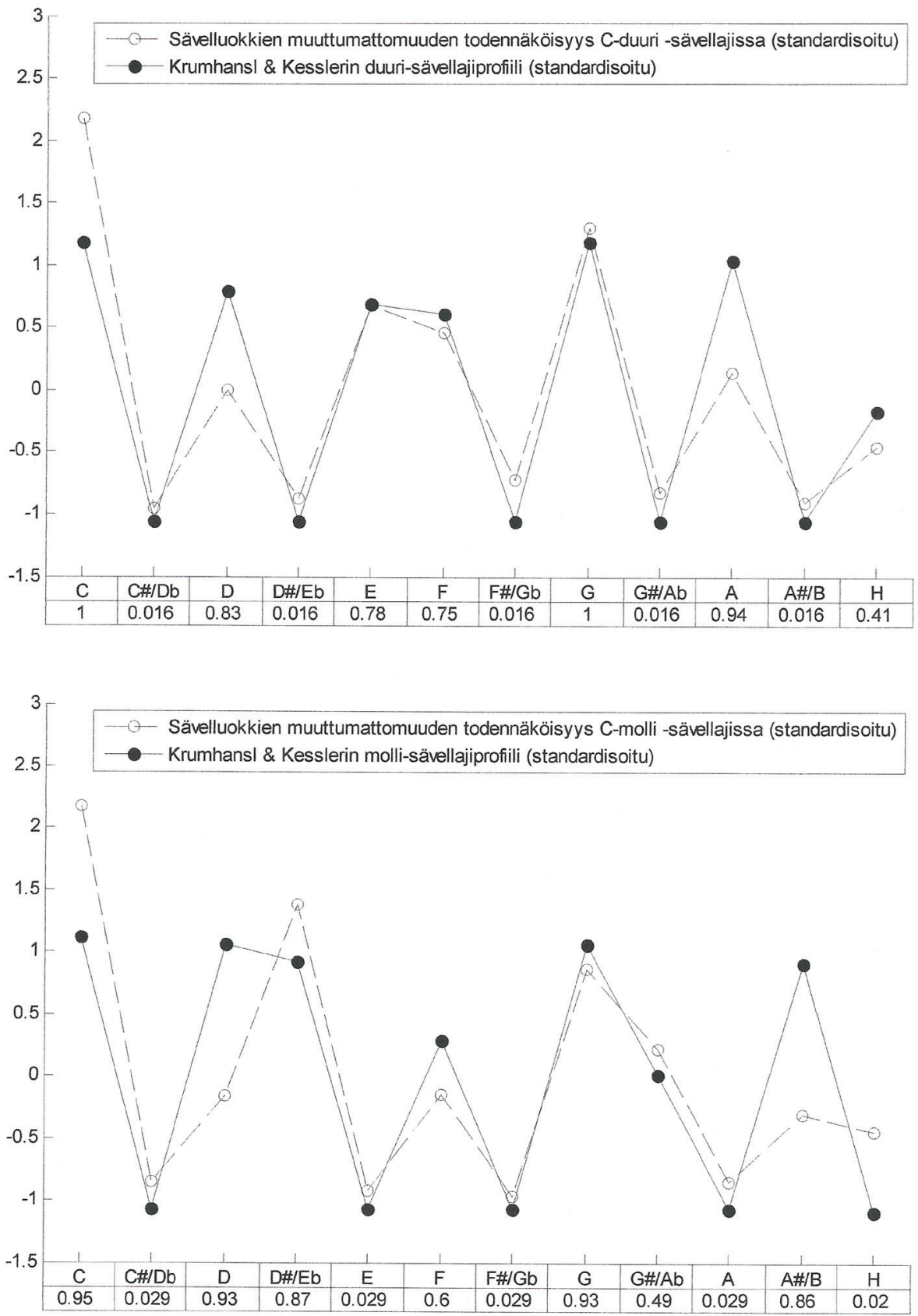

Kuva 4: Todennäköisyys-mittarin mediaaneista johdetut sävelluokkamuuttujan arvot eri sävelluokilla C-pohjaisissa sävellajeissa. Vertailukäyrinä Krumhansl \& Kesslerin (1982) sävellajiprofiilit. Vertailun helpottamiseksi kuvien arvot on standardoitu. Sävelluokkien nimien alapuolella on sävelluokkamuuttujan standardisoimattomat arvot. 
kolmannen asteen välillä (tämä koskee niin tätä aineistoa, kuin tonaalista musiikkia yleensä [vrt. Seppänen 2011]). Koska näitä tonaalisia asteita edustavien sävelien muuntuminen on epätodennäköistä, niin myös suuri seksti -intervallin kohdalla melodian muuntuminen on epätodennäköistä. Arvojen häilyvyys intervallimuuttujissa vahvistaa käsitystä, että yksittäinen säveltä edeltävä tai seuraava intervalli ei selitä muuntelun todennäköisyyden vaihtelua kovin hyvin.
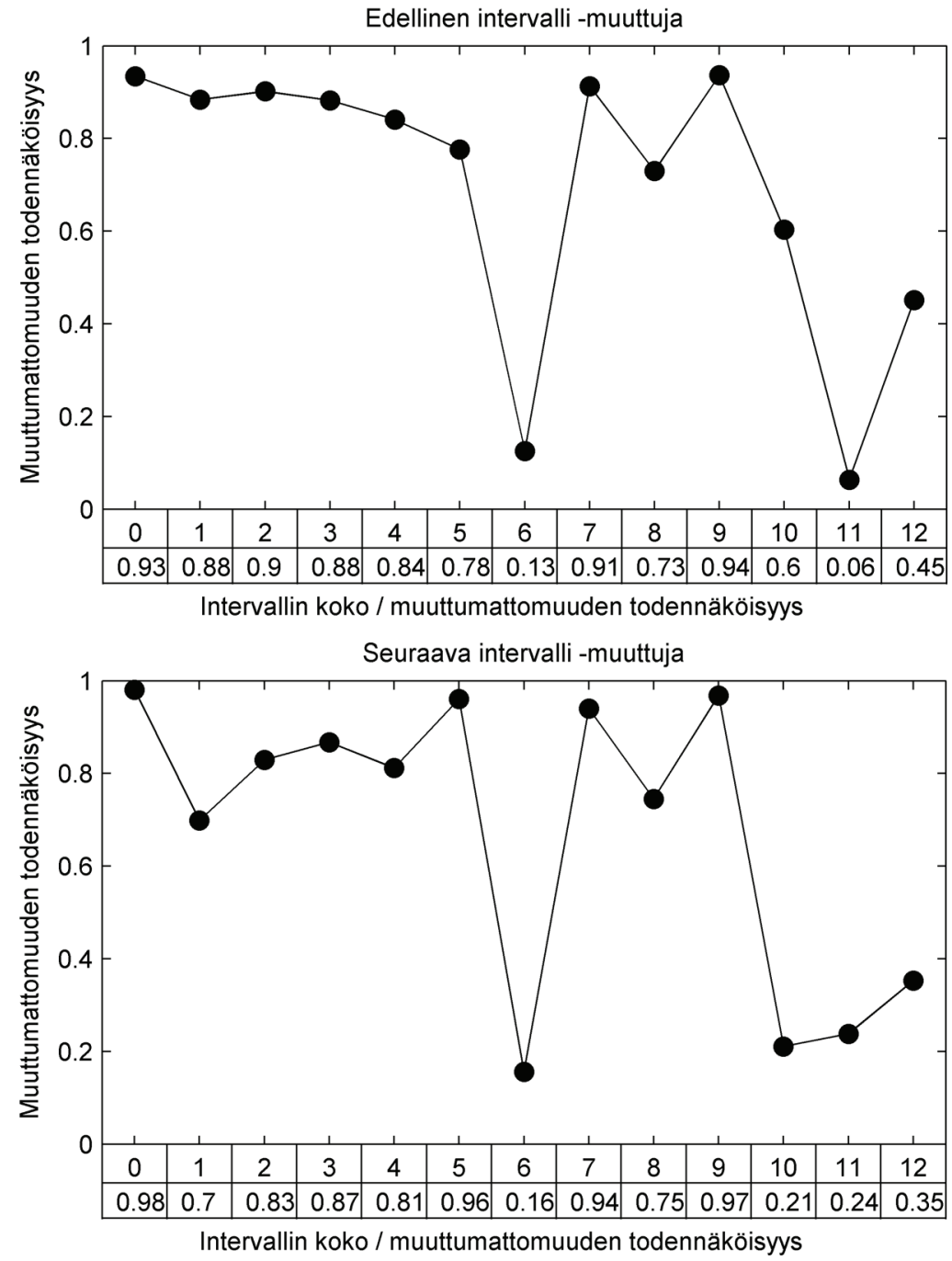

Kuva 5: Aineistosta johdetut intervalli-muuttujien arvot. 


\section{Selittävien muuttujien painoarvot}

Lopullinen robusti regressiomalli tehtiin ristiinvalidoinnissa parhaaksi osoittautuneella osa-aineistolla, jossa kussakin kahdeksassa melodiaperheessä oli vähintään 37 toisintoa. Datapisteitä osa-aineistossa 15547 kappaletta. Osa-aineisto jaettiin edelleen kahteen osaan, joista vuorollaan toista käytettiin opettavien selitettävien muuttujien opettamiseen ja toista robustiin regressioanalyysiin, jolloin tulokset ovat paremmin yleistettävissä kuin silloin, jos selittävien muuttujien opetukseen ja robustiin regressioanalyysiin olisi käytetty samaa aineistoa.

Monimuuttujaregressio-menetelmissä tavallinen ongelma on kollineaarisuus, eli selittävät muuttujien välillä voi olla korrelaatioita, jolloin muuttujat voivat peittää toistensa vaikutusta. Korrelaatiomatriisista taulukossa 3 nähdään, että selittävien muuttujien välillä ei ole suuria $(>0,9)$ korrelaatioita. Suurimmat korrelaatiot ovat sävelen metrisien painojen ja kestojen välillä $(\mathrm{rho}=0,63)$. Muuttujien multikollineaarisuutta testattiin myös vif-testillä (varianssi-inflaatiofaktori). Myöskään vIF-testin perusteella selittävien muuttujien välillä ei ollut mallin vakautta heikentävää kollineaarisuutta (vif $=1-1,5$, kun kriittisenä rajana pidetään arvoa 10).

\begin{tabular}{|c|c|c|c|c|c|c|c|}
\hline & $\begin{array}{c}\text { SIJAINTI } \\
\text { SÄKEISTÖSSÄ }\end{array}$ & $\begin{array}{l}\text { SIJAINTI } \\
\text { SÄKEESSÄ }\end{array}$ & $\begin{array}{l}\text { METRINEN } \\
\text { PAINO }\end{array}$ & KESTO & $\begin{array}{l}\text { SÄVEL- } \\
\text { LUOKKA }\end{array}$ & $\begin{array}{l}\text { EDELLINEN } \\
\text { INTERVALLI }\end{array}$ & $\begin{array}{l}\text { SEURAAVA } \\
\text { INTERVALLI }\end{array}$ \\
\hline SIJAINTI SÄKEISTÖSSÄ & 1,00 & 0,01 & 0,05 & 0,05 & $-0,09$ & $-0,06$ & $-0,07$ \\
\hline SIJAINTI SÄKEESSÄ & 0,01 & 1,00 & $-0,03$ & $-0,12$ & $-0,03$ & 0,00 & $-0,04$ \\
\hline METRINEN PAINO & 0,05 & $-0,03$ & 1,00 & 0,63 & 0,21 & 0,04 & 0,29 \\
\hline KESTO & 0,05 & $-0,12$ & 0,63 & 1,00 & 0,15 & $-0,04$ & 0,16 \\
\hline SÄVELLUOKKAM. & $-0,09$ & $-0,03$ & 0,21 & 0,15 & 1,00 & 0,25 & 0,40 \\
\hline EDELLINEN INT. & $-0,06$ & 0,00 & 0,04 & $-0,04$ & 0,25 & 1,00 & 0,17 \\
\hline SEURAAVA INT. & $-0,07$ & $-0,04$ & 0,29 & 0,16 & 0,40 & 0,17 & 1,00 \\
\hline
\end{tabular}

Taulukko 3: Selittävien muuttujien väliset Spearmanin järjestyskorrelaatiot.

Sekä todennäköisyys- että entropia-mallissa kaikki selittävät muuttujat olivat tilastollisesti erittäin merkitseviä 0,01 \%:n riskitasolla lukuun ottamatta seuraava 
intervalli -muuttujaa, jonka regressiokerroin ei ollut tilastollisesti merkitsevä. Lopullisesta mallista seuraava intervalli -muuttuja jätettiin pois. Mallin estimaatit pysyivät käytännössä vakioina käytettäessä eri aineistoja. Taulukossa 4 on muuttujien muunnosparametrit, regressiokertoimet ja standardisoidut regressiokertoimet entropian ja sävelen todennäköisyyden vaihtelua ennustavissa malleissa. Lisäksi taulukossa on keskineliövirhe ja mahdollinen selitysaste $\left(R^{2}\right)$. Suurin painoarvo molemmissa malleissa on metrisillä muuttujilla: sävelen kestolla ja metrisellä painolla (kts. standardisoidut regressiokertoimet). Seuraavat näitä alemmat painoarvot on sävelen sijaintia musiikillisessa jaksossa kuvaavilla muuttujilla. Pienin painoarvo on sävelmuuttujilla, vaikka todennäköisyysmallissa sävelluokkamuuttujan painoarvo on yhtä suuri kuin sävelen sijainnin säkeessä.

\begin{tabular}{|c|c|c|c|c|c|c|}
\hline \multicolumn{4}{|c|}{ Entropia-malli } & \multicolumn{3}{|c|}{ Todennäköisyys-malli } \\
\hline & Lambda & $\begin{array}{l}\text { Regressio- } \\
\text { kerroin }\end{array}$ & $\begin{array}{l}\text { Standardisoitu } \\
\text { regressiokerroin }\end{array}$ & Lambda & $\begin{array}{l}\text { Regressio- } \\
\text { kerroin }\end{array}$ & $\begin{array}{l}\text { Standardisoitu } \\
\text { regressiokerroin }\end{array}$ \\
\hline Selitettevä muuttuja & 0,65 & & & 9,57 & & \\
\hline Vakio & & $0,24^{*}$ & 0,01 & & $0,37^{*}$ & $-0,02$ \\
\hline Sijainti säkeistössä & 3,5 & $55,4^{*}$ & $0,21^{*}$ & 3,0 & $-122,2^{*}$ & $-0,20^{*}$ \\
\hline Sijainti säkeessä & 0,5 & $0,52^{*}$ & $0,17^{*}$ & 0,5 & $-1,23^{*}$ & $-0,17^{*}$ \\
\hline Metrinen paino & 4,0 & $-0,0002^{*}$ & $-0,26^{*}$ & 4,0 & $0,00042^{*}$ & $0,24^{*}$ \\
\hline Kesto & 1,0 & $-0,18^{*}$ & $-0,28^{*}$ & 1,0 & $0,42^{*}$ & $0,28^{*}$ \\
\hline Sävelluokka & 5,0 & $-0,09^{*}$ & $-0,14^{*}$ & 6,5 & $0,26^{*}$ & $0,17^{*}$ \\
\hline Edellinen intervalli & 5,0 & $-0,094^{*}$ & $-0,09 *$ & 6,5 & $0,27^{*}$ & $0,11^{*}$ \\
\hline Mahdollinen $\mathrm{R}^{2}$ & \multicolumn{3}{|c|}{$0,40^{*}$} & \multicolumn{3}{|c|}{$0,41^{*}$} \\
\hline Keskineliövirhe & \multicolumn{3}{|c|}{0,14} & \multicolumn{3}{|c|}{0,31} \\
\hline
\end{tabular}

${ }^{*} \mathrm{p}<0,0001$

Taulukko 4. Robustin regressioanalyysin tulokset ja muuttujien muunnosparametrit.

Molemmat mallit selittävät noin $40 \%$ muuntelun todennäköisyyden vaihtelusta. Kuvassa 6 on sirontakuviot entropia- ja todennäköisyysmallien ennustamista arvoista ja havaituista arvoista toisella robustissa regressioanalyysissä käytetyistä aineistoista. Kuvioista ja keskineliövirheestä nähdään, että todennäköisyysmitta- 

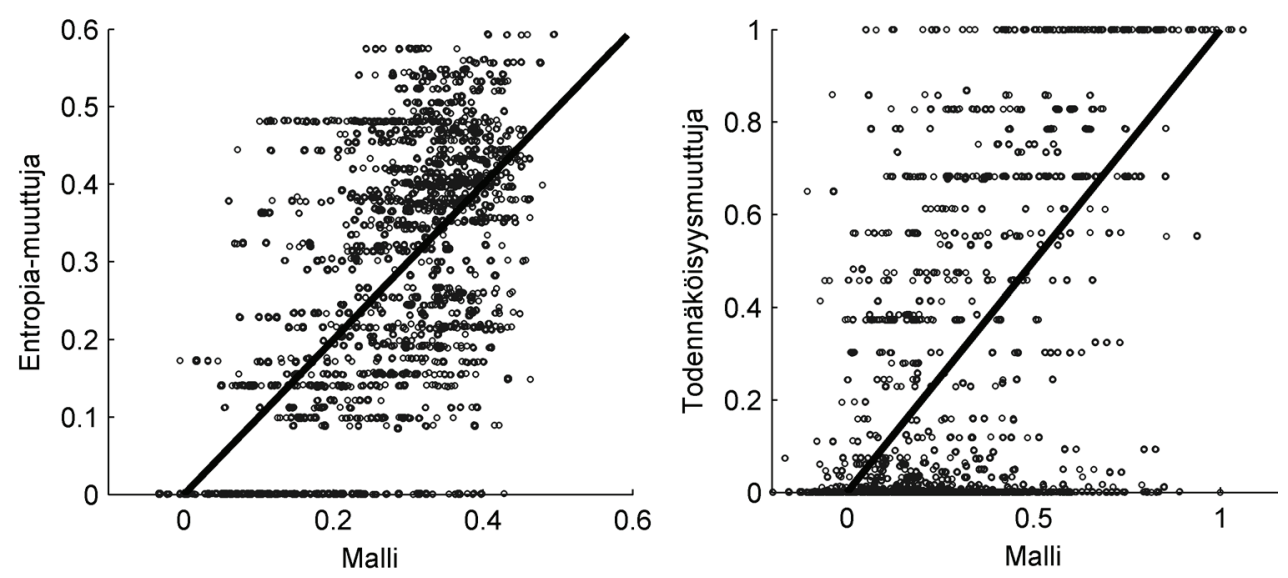

Kuva 6: Entropia- todennäköisyysmallin (robustit) regressiosuorat.

rin tapauksessa ennustetut arvot poikkeavat ennustetusta huomattavasti enemmän kuin entropia-mittarin tapauksessa. Käytetyillä musiikillisilla muuttujilla pystytään siis luotettavammin ennustamaan missä kohden melodiaperheeseen kuuluvat toisinnot yleensä muuttuvat, kuin mikä yksittäinen sävelkorkeus yksittäisessä toisinnossa muuttuu.

Huomattavin ero ja entropia-mallin ennustamien arvojen ja entropia-muuttujan arvojen välillä on entropia-muuttujan saamien o-arvojen kohdalla. Toisin sanoen malli on epäonnistunut usein melodian muuttumattomuuden ennustamisessa. On mahdollista, että suuremmat toisintojen määrät aineistossa vähentäisivät näitä tapauksia.

Vertailun vuoksi tehtiin myös pelkästään metrisiin muuttujiin ja sävelmuuttujiin perustuvat mallit. Metrisiin muuttujiin (sävelen sijainti säkeistössä ja säkeessä, metrinen paino ja sävelen kesto) perustuvan mallin mahdollinen selitysaste $\left(\mathrm{R}^{2}\right)$ oli lähes yhtä hyvä (37-38 \%) kuin mallin, joka sisälsi kaikki muuttujat joilla saatiin tilastollisesti merkitsevä regressiokerroin. Pelkästään sävelmuuttujilla pystyttiin selittämään noin $10 \%$ prosenttia muuntelun todennäköisyyden vaihtelusta. Prominenssi-sääntöön sisältyviin metriseen painoon ja sävelen sijaintiin säkeistössä perustuvan mallin selitysaste oli $30 \%$. 


\section{Päätelmät}

Tutkimuksessa selvitettiin musiikillisten muuttujien yhteyttä melodian muuntumisen todennäköisyyteen. Aineistona käytettiin toisintokokoelmaa, jossa oli 1267 toisintoa 42:sta eri sävelmästä. Aiemmista tutkimuksista poiketen tutkimuksessa huomioitiin sävelmän rakenteeseen liittyvien muuttujien (metrisen painon ja sävelen sijainnin rakenteessa) lisäksi sävelkohtaisia muuttujia, kuten sävelluokka, sävelen kesto ja säveltä edeltävä ja seuraava intervalli. Tulokset tukivat oletusta, että musiikilliset muuttujat, joiden on todettu olevan yhteydessä melodisiin odotuksiin ja melodian muistamiseen, ovat yhteydessä myös muuntelun todennäköisyyteen. Käytetyistä muuttujista parhaiten muuntelun todennäköisyyden vaihtelua selittäviksi musiikillisiksi muuttujiksi osoittautuivat metriset muuttujat, mutta myös sävelten tonaalisuudella (sävelluokkamuuttuja) ja edellisen intervallin laadulla oli tilastollisesti merkitsevä yhteys muuntelun todennäköisyyteen.

Tulokset tukivat pääpiirteittäin Sunbergin ja Lindblomin (1977) esittelemää prominenssi-sääntöä, jonka mukaan muuntelu on epätodennäköisempää metrisesti painollisissa kohdissa ja musiikillisten jaksojen lopuissa kuin muissa sävelmän kohdissa. Musiikillisten jaksojen ja muuntelun suhteeseen liittyen prominenssi-sääntöön on kuitenkin tarpeen tehdä tarkennus. Musiikillisten jaksojen aivan lopussa muuntelu on epätodennäköisempää kuin musiikillisten jaksojen alussa ja muuntelu on sitä epätodennäköisempää mitä ylemmän tason musiikillisen jakson lopusta on kyse. Edelleen musiikillisten jaksojen alussa muuntelu on epätodennäköisempää kuin musiikillisen jakson keskellä. Musiikillisen jakson aikana muuntelun todennäköisyys nousee hitaasti kunnes laskee nopeasti musiikillisen jakson lopun paikalliseen minimiin.

Tulosten yleistettävyys näytti hyvältä: ristiinvalidoinnissa saatiin hyviä tuloksia ja eri osa-aineistoilla opetetut selittävien muuttujien arvot olivat pääpiirteiltään samankaltaisia. Kattavan arvion tekeminen siitä miten hyvin tässä tutkimuksessa käytetyt tai muut musiikilliset muuttujat selittävät muuntelun todennäköisyyttä erilaisissa genreissä ja oraalisissa musiikkiperinteissä vaatisi tutkimuksia erilaisilla aineistoilla. Kuitenkin on syytä olettaa, että tulokset olisivat samankaltaisia myös toisenlaisilla aineistoilla, sillä käytetyt muuttujat liittyvät yleisesti musiikin hahmottamiseen. Mahdollisissa jatkotutkimuksissa on syytä panostaa aineiston keruuseen, sillä toisintojen määrä analysoitavissa 
melodiaperheissä vaikutti ratkaisevasti tuloksiin ja toisaalta melodiaperheiden määrä vaikuttaa tulosten yleistettävyyteen.

\section{Lähteet}

Bayard, Samuel (1950) "Prolegomena to a Study of Principal Melodic Families of BritishAmerican Folk Song". Journal of American Folklore 63, ss. 103-150.

Bereczky, János (2001) Ilmari Krohnin vaikutus unkarilaiseen kansanmusiikintutkimukseen. Jyväskylä: Jyväskylän yliopiston kirjaston julkaisuyksikkö.

Boltz, Marilyn (1991) "Some structural determinants of melody recall". Memory \& Cognition 19:3, ss. $239-251$.

Bryggman, Lorentz, Dreijer, Stig (1985) Femtio folkvisor från Åland. 3. painos. Maarianhamina: Ålands folkminnesförbund.

Clarke, E. F. (1985) "Some aspects of rhythm and expression in performances of Erik Satie's 'Gnossienne No. 5.'", Music Perception 2, ss. 299-328.

Conley, J. K. (1981) "Physical correlates of the judged complexity of music by subjects differing in musical background". British Journal of Psychology 72, ss. 451-464.

Cuddy, L., Cohen, A., \& Miller, J. (1979) “Melody recognition: The experimental application of musical rules". Canadian Journal of Psychology 33, ss. 148-157

Cuddy, L., Cohen, A., \&: Mewhotr, D. (1981) “Perception of structure in short melodic sequences". Journal of Experimental Psychology: Human Perception E Performance 7, ss. 860-883.

Dewitt, L. A., \& Crowder, R. G. (1986) “Recognition of novel melodies after brief delays”. Music Perception 3:2, ss. 259-274.

Dowling W. Jay (1991) “Tonal strength and melody recognition after long and short delays". Perception \& Psychophysics 50:4, ss. 305-313

Eerola, T. \& North, A. C. (2000) "Expectancy-Based Model of Melodic Complexity". Proceedings of the Sixth International Conference on Music Perception and Cognition. Toim. C. Woods, G.B. Luck, R. Brochard, S. A. O’Neill \& J. A. Sloboda. Keele, Staffordshire, uk: Department of Psychology. 
Eerola, T., Himberg , T., Toiviainen, P., Louhivuori, J. (2006) “Perceived complexity of western and African folk melodies by Western and African listeners". Psychology of Music, 34:3, ss. $337-371$.

Fleiss, J. L. (1971) "Measuring nominal scale agreement among many raters". Psychological Bulletin $76: 5$, ss. $378-382$

Jones, Maser \& Kidd (1978) "Rate and structure in memory for auditory patterns". Memory $\mathcal{E}$ Cognition. 6:3, ss. 246-258.

Krumhansl, C. L. (1990) Cognitive Foundations of Musical Pitch. New York: Oxford University Press.

Krumhansl, C. L. (1995) "Effects of musical context on similarity and expectancy". Systematische musikwissenschaft 3, ss. 211-250.

Krumhansl, C. L., \& Kessler, E. J (1982) “Tracing the dynamic changes in perceived tonal organization in a spatial representation of musical keys". Psychological Review 89, ss. 334-368.

Louhivuori, Jukka (1988) Veisuun vaihtoehdot: musiikillinen distribuutio ja kognitiiviset toiminnot. Helsinki: Suomen Musiikkitieteellinen Seura.

Manzara , Leonard C., Witten Ian H. \& Mark James (1992) "On the Entropy of Music: An Experiment with Bach Chorale Melodies". Leonardo Music Journal Vol. 2, No. 1, ss. 81-88.

Narmour, Eugene (1990) The Analysis and cognition of basic melodic structures: The Implicationrealization model. Chicago, IL: University of Chicago Press.

Nettl, B. (2005) The Study of Ethnomusicology: Thirty-one Issues and Concepts. Urbana \& Chicago: University of Illinois Press, 2 edition.

Povel, D. J., \& Essens, P. (1985) “Metrical and nonmetrical representations of temporal patterns". Perception and Psychophysics 37, ss. 1-7.

Schellenberg, E. G. (1997) "Simplifying the implication-realization model of melodic expectancy". Music Perception 14, ss. 295-318.

Schmuckler, M. A. (1997) "Expectancy effects in memory for melodies". Canadian Journal of Experimental Psychology 51, ss. 292-306.

Schulkind, M.D., Posner, R.J., \& Rubin, D.C. (2003) “Music Features that Facilitate Melody Identification: How do you Know it's 'your' Song when they Finally Play It?" Music Perception 21, ss. 217-249.

Seppänen, Janne (2011) "Algoritminen sävellajin tunnistus painotetulla äänestyksellä". Musiikkilehti 2/2011, ss. 6-21.

Sharp Cecil (1907): English Folk-Song: Some Conclusions. London: Simpkin \& Co. 
Snyder, John L. (1990): “Entropy as a Measure of Musical Style: The Influence of A Priori Assumptions". Music Theory Spectrum 12:1, ss. 121-160.

Sundberg, Johan \& Lindblom Björn (1976) "Generative theories in language and music descriptions". Cognition 4, ss. 99-122

Särg, Taive \& Ambrazevi囚ius, Rytis (2007) “Melodic accent in Estonian and Lithuanian folk songs". Proceedings of the third Conference on Interdisciplinary Musicology (CIMo7). Toim. K. Maimets-Volt, R. Parncutt, M Marin \& J. Ross. Tallinna: Estonian Academy of Music and Theatre. Ss. $136-137$.

Särg, Taive (2006) "Does melodic accent shape the melody contour in Estonian folk songs?" International Conference on Music Perception and Cognition. Alma Mater Studiorum University of Bologna.

Thomassen, J. M. (1982) "Melodic accent: Experiments and a tentative model". Journal of the Acoustical Society of America 71, ss. 1596-1605.

Volk, Anja; de Haas, W. Bas \& van Kranenburg, Peter (2012): “Towards Modelling Variation in Music as Foundation for Similarity". Proceedings of the 12th International Conference on Music Perception and Cognition and the 8th Triennial Conference of the European Society for the Cognitive Sciences of Music. Thessaloniki. 2012, ss. 1085-1094.

Volk, Anja \& van Kranenburg, Peter (2012): “Melodic similarity among folk songs: An annotation study on similarity-based categorization in music". Musicae Scientiae, http:/ /msx.sagepub. com/content/early/2012/07/23/1029864912448329.full.pdf (luettu 27.9.2012).

Wiora, Walter (1941) "Systematik der musikalischen Erscheinungen des Umsingens". Jahrbuch für Volksliedforschung 7, ss. 128-195. 